\title{
Brazilian maize genotypes sensitivity to water deficit estimated through a simple crop yield model
}

\author{
Kleber Gustavo Andrioli(1) and Paulo Cesar Sentelhas ${ }^{(1)}$ \\ (1)Universidade de São Paulo, Escola Superior de Agricultura Luiz de Queiroz, Departamento de Engenharia Rural, Avenida Pádua Dias, no 11, \\ Caixa Postal 9, CEP 13418-900 Piracicaba, SP, Brazil. E-mail: kleberg_andrioli@hotmail.com, pcsentel@esalq.usp.br
}

\begin{abstract}
The objective of this work was to determine the sensitivity of maize (Zea mays) genotypes to water deficit, using a simple agrometeorological crop yield model. Crop actual yield and agronomic data of 26 genotypes were obtained from the Maize National Assays carried out in ten locations, in four Brazilian states, from 1998 to 2006. Weather information for each experimental location and period were obtained from the closest weather station. Water deficit sensitivity index (Ky) was determined using the crop yield depletion model. Genotypes can be divided into two groups according to their resistance to water deficit. Normal resistance genotypes had Ky ranging from 0.4 to 0.5 in vegetative period, 1.4 to 1.5 in flowering, 0.3 to 0.6 in fruiting, and 0.1 to 0.3 in maturing period, whereas the higher resistance genotypes had lower values, respectively $0.2-0.4,0.7-1.2,0.2-0.4$, and $0.1-0.2$. The general Ky for the total growing season was 2.15 for sensitive genotypes and 1.56 for the resistant ones. Model performance was acceptable to evaluate crop actual yield, whose average errors estimated for each genotype ranged from $-5.7 \%$ to $+5.8 \%$, and whose general mean absolute error was $960 \mathrm{~kg} \mathrm{ha}^{-1}(10 \%)$.

Index Terms: Zea mays, agrometeorology, drought resistance, water balance.

\section{Sensibilidade de genótipos brasileiros de milho ao deficit hídrico, estimada por um modelo simples de produtividade}

Resumo - O objetivo deste trabalho foi determinar a sensibilidade de genótipos de milho (Zea mays) ao deficit hídrico, pelo uso de um modelo agrometeorológico simples de estimativa de produtividade. Dados de produtividade real e agronômicos de 26 genótipos foram obtidos dos Ensaios Nacionais de Milho, em dez localidades, em quatro estados brasileiros, entre 1998 e 2006. Os dados meteorológicos, para cada experimento e período, foram obtidos das estações mais próximas de cada local. O índice de sensibilidade ao deficit hídrico (Ky) dos genótipos foi determinado por meio do modelo de depleção da produtividade. Os genótipos de milho podem ser classificados em dois grupos de resistência ao deficit hídrico. Os de resistência normal tiveram Ky entre 0,4 e 0,5 no período vegetativo, 1,4 e 1,5 no florescimento, 0,3 e 0,6 na frutificação, e 0,1 e 0,3 no período de maturação, enquanto os genótipos de maior resistência tiveram, respectivamente, os seguintes valores de Ky: $0,2-0,4 ; 0,7-1,2 ; 0,2-0,4 ;$ e $0,1-0,2$. Em todo o ciclo, o Ky geral foi 2,15 nos genótipos mais sensíveis, e 1,56 nos de maior resistência ao deficit hídrico. O desempenho do modelo foi aceitável para a avaliação da produtividade real, cujos erros médios estimados para cada genótipo variaram de $-5,7$ a $+5,8 \%$, e cujo erro absoluto médio geral foi de $960 \mathrm{~kg} \mathrm{ha}^{-1}(10 \%)$.

Termos para Indexação: Zea mays, agrometeorologia, resistência à seca, balanço hídrico.

\section{Introduction}

Maize (Zea mays L.) is an essential crop for food security around the world (Campos et al., 2004), and becomes also very important for energetic purposes, considering that it is the main raw material for ethanol production in temperate countries of North America, Europe and Asia (Pimentel $\&$ Patzek, 2005), where automotive industry demand for maize ethanol rises every year. It is estimated that by the year 2020, the demand could increase beyond 125 billion liters of maize ethanol per year (Demirbas, 2007).
In Brazil, maize is the second most important grain crop, both in cultivated and production areas, just after soybean. According to Companhia Nacional de Abastecimento (2008), in the 2007/2008 growing season, the cultivated area was 14.8 million ha, and the total production was approximately 59 million tons. The country is the fourth world producer of maize, with an average yield of four tons per hectare. This yield is still very low, considering the crop potential, which can achieve 16 tons per hectare (Coelho et al., 2003). 
Water deficit occurrences during the crop cycle are one of the most limiting factors for maize yield around the world (Kenny \& Harrison, 1992; Bergamaschi et al., 2004; Ouda et al., 2008). In Brazil, Bergamaschi et al. (2007) consider the irregular distribution of rainfall during the crop cycle as the main factor to explain variability in maize yield, mainly in the state of Rio Grande do Sul, where El Niño Southern Oscillation has a great influence on rainfall patterns (Berlato et al., 2005). Bergonci et al. (2001) and Bergamaschi et al. $(2004,2006)$ reported an extreme sensitivity of maize plants to water deficit from flowering to the beginning of the grain-filling period, when plants had the highest water consumption, as a consequence of their maximum leaf area index, and the highest atmospheric evaporative demand. According to Bergamaschi et al. (2006), the highest maize yield reduction occurs when water deficit happen, during pollination, zygote formation and initial grain development. During these periods, the water deficit causes around $70 \%$ of the variations in grain yield.

Maize sensitivity to water stress over the whole growing season or at one of the different growth stages has been widely used in studies for the development of deficit irrigation strategies, and for determinations of the yield response factor, also known as water deficit sensitivity index (Ky). This index is derived from the linear relationship between relative seasonal evapotranspiration deficits $[1-\mathrm{ETa} / \mathrm{ETc}]$ and relative yield loss [1 - Ya/Yp], and have been used as a parameter in maize yield models (Musik \& Dusek, 1980; Doorenbos \& Kassam, 1994; Dagdelen et al., 2006; Mengu et al., 2008).

The knowledge of Ky makes it possible to choose the best crops and genotypes for a specific location and season, according to water deficit conditions, reducing yield losses during the growing season. As maize is moderately drought-sensitive, and each of its developmental periods has a different sensitivity to water stress, the degree of yield loss will depend on the stage in which water deficit occurs, as well as on the genotype resistance. In Brazil, maize is cultivated in the spring-summer season, when weather is hot and humid, and in the fall-winter season ("safrinha"), when water deficits are more frequent. Therefore, the knowledge of Ky of maize genotypes can help growers and other decision makers to choose the best ones for their climatic conditions.
Besides, global climate change is expected to result in a long-term trend towards higher temperatures, greater evapotranspiration, and an increased incidence of droughts in specific regions. These factors coupled with an expansion of cropping in marginal production areas are generating increasingly drought-prone maize production environments, where drought-resistant genotypes should be used (Campos et al., 2004).

The objective of this study was to determine the sensitivity to water deficit in 26 Brazilian maize genotypes, by using a simple agrometeorological crop yield model.

\section{Materials and Methods}

Maize actual yield (Ya) and agronomic data for 26 genotypes were obtained from the Ensaios Maize National Assays, conducted by Empresa Brasileira de Pesquisa Agropecuária (Embrapa), from 1998 to 2006, totaling 244 experiments sowed between October and December, and harvested between March and June, under rainfed conditions. The number of trials per genotype ranged from five to 17 , and the genotypes used were those available in all trials and locations during the considered period. The main characteristics of each genotype used in this study are shown in Table 1. The assays were done in the following states: Paraná (Cascavel, Londrina and Ponta Grossa counties); São Paulo (Piracicaba county); Minas Gerais (Inhaúma, Lavras and Sete Lagoas counties); and Goiás (Santa Helena do Goiás and Senador Canedo counties), comprising latitudes between $16^{\circ} 40^{\prime}$ and $25^{\circ}$ South, an longitudes between $44^{\circ} 15^{\prime}$ and $53^{\circ} 30^{\prime}$ 'West.

Weather data for each location and period were obtained from the closest weather station, including data from Instituto Tecnológico Simepar, for locations in the state of Paraná; Escola Superior de Agricultura Luiz de Queiroz - Universidade de São Paulo, for Piracicaba, state of São Paulo; and from Agritempo - Embrapa Informática Agropecuária, for locations in the states of Minas Gerais and Goiás.

Weather data considered were the following: average temperature $\left(\mathrm{T}_{\text {avg }}\right)$; maximum temperature $\left(\mathrm{T}_{\max }\right)$; minimum temperature $\left(\mathrm{T}_{\min }\right)$; rainfall $(\mathrm{R})$; extraterrestrial solar radiation (SRo); daylight period or photoperiod $(\mathrm{N})$; and effective hours of sunshine (n). As the effective hours of sunshine data were not available for all locations, they were 
estimated for these locations using the combination of Angströn-Prescott (Pereira et al., 2002) and Hargreaves equations (Allen et al., 1998): SR/SRo $=a+b(n / N)$ and $\mathrm{SR} / \mathrm{SRo}=0.16\left(\mathrm{~T}_{\max }-\mathrm{T}_{\min }\right)^{0.5}$, in which: $\mathrm{SR}$ is the global solar radiation; and $\mathrm{a}$ and $\mathrm{b}$ are, respectively, the intercept and the slope of the linear regression, defined by Glover \& McCulloch (1958) as $\mathrm{a}=0.29 \cos \varnothing$, being $\varnothing=$ latitude, and $\mathrm{b}=0.52$.

Such combination resulted in the following equation, which estimates $\mathrm{n}$ as a function of $\mathrm{T}_{\max }$ and $\mathrm{T}_{\min }$ : $\mathrm{n}=\mathrm{N}\left\{\left[0.16\left(\mathrm{~T}_{\max }-\mathrm{T}_{\min }\right)^{0.5}-0.29 \cos \varnothing\right] / 0.52\right\}$

Doorenbos \& Kassam (1994) crop yield models to estimate potential (Yp) and actual (Ya) yields were used to determine the water deficit sensitivity index (Ky) for the 26 maize genotypes, in each one of the four crop developmental periods, and for the entire crop cycle. Potential yield refers to the crop yield obtained by the interaction between the genotype and the uncontrolled weather variables, like solar radiation, photoperiod and temperature (De Wit, 1965). Actual yield refers to the yield obtained from crop influenced by the effect of the above mentioned weather variables, and also by water deficit during the growing season (Pereira et al., 2002). Actual yield equals to Yp when maize experiences no water deficit, and is smaller than Yp when water deficit occurs.

The model used for estimating Yp is known as agroecological zone model (Doorenbos \& Kassam, 1994), and is based on the assumption that the crop is under optimal growing conditions, without water, nutrients or phytosanitary stresses. The model is given by:

$\mathrm{Yp}=\sum_{\mathrm{i}=1}^{\mathrm{m}} \mathrm{GP}_{\mathrm{i}} \cdot \mathrm{C}_{\mathrm{LAI}} \cdot \mathrm{C}_{\mathrm{RESP}} \cdot \mathrm{C}_{\mathrm{H}} \cdot\left(1-\mathrm{C}_{\mathrm{W}}\right)^{-1}$,

in which: GP is the gross photosynthesis, expressed in kilogram of dry matter per hectare per day; $\mathrm{C}_{\mathrm{LAI}}$ is the depletion coefficient, related to leaf area index (LAI); $\mathrm{C}_{\text {RESP }}$ is the depletion coefficient associated to the maintenance respiration process, which is a function of the air temperature; $\mathrm{C}_{\mathrm{H}}$ is the crop harvest index; $\mathrm{C}_{\mathrm{W}}$ is the coefficient to consider the water content in the harvested part of the plant; $i$ is the day in the crop cycle; and $\mathrm{m}$ is the number of days of the crop cycle, from sowing to harvesting. The final result of Yp is given in $\mathrm{kg} \mathrm{ha}^{-1}$.

The GP is estimated by the sum of the gross photosynthesis, obtained in the fraction of the day with clear sky $\left(\mathrm{GP}_{\mathrm{C}}\right)$ and in the fraction overcast $\left(\mathrm{GP}_{\mathrm{O}}\right)$, as

Table 1. Agronomic characteristics of the 26 maize Brazilian genotypes ${ }^{(1)}$.

\begin{tabular}{|c|c|c|c|c|c|c|c|c|c|c|c|}
\hline Genotype & Type & Cycle & $\begin{array}{c}\text { Degree } \\
\text { days }\end{array}$ & $\begin{array}{c}\text { Sowing } \\
\text { period }\end{array}$ & Use & $\begin{array}{l}\text { Grain } \\
\text { color }\end{array}$ & $\begin{array}{l}\text { Grain } \\
\text { texture }\end{array}$ & $\begin{array}{c}\text { Resistance to } \\
\text { lodging }\end{array}$ & $\begin{array}{c}\text { Cob } \\
\text { height }(\mathrm{m})\end{array}$ & $\begin{array}{c}\text { Plant } \\
\text { height }(\mathrm{m})\end{array}$ & $\begin{array}{c}\text { Technological } \\
\text { level }\end{array}$ \\
\hline AG 1051 & HD & SS & 950 & $\mathrm{E} / \mathrm{N} / \mathrm{L} / \mathrm{S}$ & G/SW/SC & $\mathrm{Y}$ & $\mathrm{D}$ & $\mathrm{H}$ & 1.60 & 2.60 & $\mathrm{M} / \mathrm{H}$ \\
\hline AG 6018 & HT & VS & 830 & $\mathrm{E} / \mathrm{N}$ & G & $\mathrm{Y} / \mathrm{DY}$ & $\mathrm{H}$ & $\mathrm{H}$ & 1.10 & 2.20 & $\mathrm{H}$ \\
\hline AL Bandeirante & $\mathrm{V}$ & SS & 900 & $\mathrm{~N} / \mathrm{S}$ & G/SW & DY & $\mathrm{SH}$ & M & 1.25 & 2.25 & $\mathrm{~L} / \mathrm{M}$ \\
\hline AS 3466 Top & HT & $\mathrm{S}$ & 845 & $\mathrm{~N} / \mathrm{S}$ & $\mathrm{G}$ & $\mathrm{R}$ & $\mathrm{H}$ & $\mathrm{H}$ & 1.05 & 2.10 & $\mathrm{M} / \mathrm{H}$ \\
\hline AS 1533 & $\mathrm{HSm}$ & $\mathrm{S}$ & 839 & $\mathrm{~N} / \mathrm{S}$ & $\mathrm{G}$ & $\mathrm{R}$ & $\mathrm{H}$ & $\mathrm{H}$ & 1.00 & 2.10 & $\mathrm{M} / \mathrm{H}$ \\
\hline BALU 178 & HT & $\mathrm{S}$ & 860 & $\mathrm{E} / \mathrm{N} / \mathrm{S}$ & G/SW & DY & $\mathrm{H}$ & $\mathrm{H}$ & SI & 2.09 & $\mathrm{M}$ \\
\hline BALU 184 & HD & $\mathrm{S}$ & 860 & $\mathrm{E} / \mathrm{N} / \mathrm{S}$ & G/SW & $\mathrm{R}$ & $\mathrm{H}$ & $\mathrm{H}$ & SI & 2.00 & M \\
\hline BRS 3060 & HT & SS & 762 & $\mathrm{E} / \mathrm{N} / \mathrm{T} / \mathrm{S}$ & G/SW & DY & SD & M & 1.30 & 2.40 & $\mathrm{M} / \mathrm{H}$ \\
\hline CD 3121 & HS & $\mathrm{S}$ & 856 & $\mathrm{~N} / \mathrm{S}$ & G/SW & $\mathrm{Y}$ & SD & $\mathrm{H}$ & 1.28 & 2.19 & $\mathrm{M} / \mathrm{H}$ \\
\hline $\mathrm{CO} 32$ & HT & $\mathrm{S}$ & 848 & $\mathrm{E} / \mathrm{N} / \mathrm{L} / \mathrm{S}$ & $\mathrm{G}$ & $\mathrm{O}$ & $\mathrm{SH}$ & M & 1.10 & 2.10 & $\mathrm{M} / \mathrm{H}$ \\
\hline DKB 333 B & $-^{(2)}$ & - & - & - & - & - & - & - & - & - & - \\
\hline DKB 350 & HT & $\mathrm{S}$ & 860 & $\mathrm{E} / \mathrm{N} / \mathrm{L} / \mathrm{S}$ & $\mathrm{G}$ & DY & $\mathrm{SH}$ & $\mathrm{H}$ & 1.20 & 2.20 & $\mathrm{H}$ \\
\hline DKB 747 & HD & $\mathrm{S}$ & 845 & N/L/S & G/SW & DY & $\mathrm{H}$ & $\mathrm{H}$ & 1.20 & 2.20 & M \\
\hline Farroupilha 25 & HT & $\mathrm{S}$ & 860 & $\mathrm{~N}$ & $\mathrm{G}$ & SI & $\mathrm{H}$ & $\mathrm{H}$ & 1.18 & 2.20 & $\mathrm{M}$ \\
\hline P 3041 & HT & $\mathrm{S}$ & 851 & $\mathrm{~N} / \mathrm{L} / \mathrm{S}$ & G/SW & DY & $\mathrm{H}$ & $\mathrm{M}$ & $1.25-1.35$ & $2.30-2.50$ & $\mathrm{M} / \mathrm{H}$ \\
\hline Р 3081 & - & - & - & - & - & - & - & - & - & - & - \\
\hline P $30 F 33$ & HS & $\mathrm{S}$ & - & $\mathrm{N} / \mathrm{L} / \mathrm{S}$ & G & DY & $\mathrm{H}$ & M & $1.25-1.35$ & $2.40-2.60$ & $\mathrm{M} / \mathrm{H}$ \\
\hline PL 6880 & $\mathrm{HT}$ & $\mathrm{N}$ & - & $\mathrm{N} / \mathrm{S}$ & G/SW & $\mathrm{Y}$ & D & M & 1.35 & 2.62 & M \\
\hline SHS 4050 & HD & VS & 830 & $\mathrm{E} / \mathrm{N} / \mathrm{S}$ & $\mathrm{G} / \mathrm{SG}$ & $\mathrm{O}$ & $\mathrm{H}$ & $\mathrm{H}$ & 1.10 & 2.10 & $\mathrm{M} / \mathrm{H}$ \\
\hline SHS 5050 & HT & VS & 810 & $\mathrm{E} / \mathrm{N} / \mathrm{S}$ & $\mathrm{G} / \mathrm{SG}$ & DY & $\mathrm{SH}$ & M & 1.10 & 2.00 & $\mathrm{M} / \mathrm{H}$ \\
\hline SHS 5060 & HT & $\mathrm{S}$ & 855 & $\mathrm{E} / \mathrm{N} / \mathrm{L} / \mathrm{S}$ & G/SW & $\mathrm{Y}$ & SD & $\mathrm{H}$ & 1.30 & 2.30 & $\mathrm{M} / \mathrm{H}$ \\
\hline SHS 5070 & HT & VS & 820 & $\mathrm{E} / \mathrm{N} / \mathrm{S}$ & $\mathrm{G} / \mathrm{SG}$ & $\mathrm{O}$ & $\mathrm{H}$ & M & 1.10 & 2.10 & $\mathrm{M} / \mathrm{H}$ \\
\hline SHS 4040 & HD & $\mathrm{S}$ & 850 & $\mathrm{E} / \mathrm{N} / \mathrm{L} / \mathrm{S}$ & G/SW & $\mathrm{O}$ & $\mathrm{H}$ & $\mathrm{H}$ & 1.30 & 2.40 & $\mathrm{M} / \mathrm{H}$ \\
\hline XB 7011 & HT & $\mathrm{S}$ & 866 & $\mathrm{E} / \mathrm{N} / \mathrm{S}$ & G & $\mathrm{O}$ & $\mathrm{H}$ & $\mathrm{MH}$ & 1.15 & $2.05-2.25$ & $\mathrm{M} / \mathrm{H}$ \\
\hline XB 7012 & HT & $\mathrm{S}$ & 884 & $\mathrm{E} / \mathrm{N} / \mathrm{S}$ & $\mathrm{G}$ & $\mathrm{O}$ & $\mathrm{H}$ & $\mathrm{MH}$ & 0.95 & $1.85-2.00$ & $\mathrm{M} / \mathrm{H}$ \\
\hline XB 8010 & HD & $\mathrm{S}$ & 835 & $\mathrm{E} / \mathrm{N} / \mathrm{L} / \mathrm{S}$ & $\mathrm{G}$ & $\mathrm{O}$ & $\mathrm{H}$ & $\mathrm{MH}$ & 0.95 & $2.00-2.15$ & $\mathrm{~L} / \mathrm{M} / \mathrm{H}$ \\
\hline
\end{tabular}

(1)Type: V, variety; HD, double hybrid; HT, triple hybrid; HS, simple hybrid; HSm, modified simple hybrid. Cycle: VS, very short; S, short; SS, semi short; N, normal. Sowing period: E, summer early; N, summer normal; L, summer late; S, fall-winter ("safrinha"). Use: G, grain; SW, silage of whole plant; SG, silage of humid grain; SC, sweet corn. Grain color: DY, dark yellow; O, orange; R, red; Y, yellow. Grain texture: H, hard; SH, semi-hard; D, dent; SD, semi-dent. Resistance to lodging: H, high; M, medium; MH, medium to high. Technological level: H, high; M, medium; L, low. ${ }^{(2)}$ Without information. 
follows: $\mathrm{GP}=\mathrm{GP}_{\mathrm{C}}+\mathrm{GP}_{\mathrm{O}}$, with: $\mathrm{GP}_{\mathrm{C}}=(107.2+0.36 \mathrm{SRo})$ cTc $(1-n / N)$ and $\mathrm{GP}_{\mathrm{O}}=(31.7+0.219 \mathrm{SRo}) \mathrm{cTo}(\mathrm{n} / \mathrm{N})$, in which: cTc and cTo are coefficients associated to the efficiency of the photosynthetic process, regarding the type of crop and its metabolism to atmospheric $\mathrm{CO}_{2}$ fixation. Both coefficients are temperature-dependent and are calculated by the following quadratic equations for C4 plants (Barbieri \& Tuon, 1992; Pereira et al. 2002): $\mathrm{cTc}=-4.16+0.4325 \mathrm{~T}_{\mathrm{avg}}-0.00725 \mathrm{~T}_{\mathrm{avg}}{ }^{2}$ and $\mathrm{cTo}=-1.064+0.173 \mathrm{~T}_{\mathrm{avg}}-0.0029 \mathrm{~T}_{\mathrm{avg}}{ }^{2}$.

The other coefficients of the agroecological zone model were determined following Barbieri \& Tuon (1992), Doorenbos \& Kassam (1994) and Pereira et al. (2002). The leaf area index coefficient $\left(\mathrm{C}_{\mathrm{LAI}}\right)$ was estimated by a quadratic equation, as a function of the maximum LAI which varied among genotypes, ranging from 0.36 to 0.56 in the present study. The respiration coefficient $\left(\mathrm{C}_{\mathrm{RESP}}\right)$ was considered to be 0.5 , when average temperature was $>20^{\circ} \mathrm{C}$ during the cycle, and 0.6 when $\leq 20^{\circ} \mathrm{C}$. The harvest $\left(\mathrm{C}_{\mathrm{H}}\right)$ and water content $\left(\mathrm{C}_{\mathrm{W}}\right)$ coefficients for maize crop were 0.40 and 0.13 , respectively.

The Yp data estimated with the equation of the agroecological zone model, for each one of the 244 experiments, were used together with water balance data to estimate Ya, using the linear crop-water production function of Doorenbos \& Kassam (1994):

$$
\mathrm{Ya}=\mathrm{Yp} \prod_{\mathrm{i}=1}^{\mathrm{m}}\left[1-\mathrm{Ky}_{\mathrm{i}}\left(1-\frac{\mathrm{ETa}_{\mathrm{i}}}{\mathrm{ETc}_{\mathrm{i}}}\right)\right] \text {, }
$$

in which: Ky is the crop sensitivity index to water deficit, also known as yield response factor, which is crop-specific and vary over the growing season according to growth stage; ETa is the actual crop evapotranspiration; and ETc is the maximum crop evapotranspiration. ETc was calculated by the product between potential evapotranspiration (ETP), estimated by Thornthwaite (1948) method, and crop coefficient $(\mathrm{Kc})$. Actual crop evapotranspiration is an output of the crop water balance, calculated by the Thornthwaite \& Mather (1955) model, using the spreadsheet elaborated by Rolim et al. (1998). The standard Kc (0.40 for establishment, 0.80 for vegetative growth, 1.10 for flowering, 0.90 for yield formation and 0.55 for ripening) and Ky (0.0 for establishment, 0.4 for vegetative growth, 1.5 for flowering, 0.5 for yield formation and 0.2 for ripening) values, used to calculate respectively ETc and Ya, were applied to generate the first round of Ya values. After that, the calibration of the model was done through Ky manipulation to obtain the best fit between the observed and the estimated Ya, for each one of the genotypes. The degree of resistance to water deficit was measured by the Ky values. Smaller Ky values represent a greater resistance and vice-versa.

The process of crop yield model calibration was used to determine the Ky values for the different growth periods of each genotype. The calibration of Ky values aimed to obtain the smallest mean absolute error (MAE) between the observed and the estimated Ya, by an interactive process. This procedure was done in a programmed Microsoft Excel spreadsheet, in which other statistical indices were also calculated as: correlation coefficient (r); agreement index (d); and performance index (c). The correlation coefficient (r) is a measure of precision, whereas the agreement index (d) is a measure of accuracy (Willmott et al., 1985). In the present study, both $\mathrm{r}$ and $\mathrm{d}$ indexes ranged from 0 to 1 , where 0 means no correlation or agreement, and 1 means perfect correlation or agreement. The index $\mathrm{d}$ is calculated by the equation: $\mathrm{d}=1-\left[\sum(\mathrm{Pi}-\mathrm{Oi})^{2} / \sum(|\mathrm{Pi}-\mathrm{O}|+|\mathrm{Oi}-\mathrm{O}|)^{2}\right]$, in which: $\mathrm{Pi}$ is the estimated $\mathrm{Ya}$; $\mathrm{Oi}$ is the observed $\mathrm{Ya}$; and $\mathrm{O}$ is the average of the observed Ya. The index $\mathrm{c}$ also ranges from 0 to 1, and multiplies precision (r) and accuracy (d), as proposed by Camargo \& Sentelhas (1997).

The mean bias error (MBE), which gives the direction of the predominant error, and the mean absolute error (MAE), which gives the magnitude of the error, were also determined between the observed and the estimated Ya.

\section{Results and Discussion}

The yield model calibration process resulted in different values of $\mathrm{Ky}$ for the studied genotypes (Table 2). The majority of the genotypes (18) was considered as of normally resistant to water deficit, since their Ky values did not differ substantially from those showed by Doorenbos \& Kassam (1994). The normal-resistance genotypes had Ky ranging from 0.4 to 0.5 for the vegetative growth period, 1.4 to 1.5 for flowering, 0.3 to 0.6 for the yield formation period, and 0.1 to 0.3 for ripening, and the higher-resistance genotypes had lower values, respectively: 0.2-0.4, $0.7-1.2,0.2-0.4$, and $0.1-0.2$. The greatest difference between the two groups was observed for the flowering 
period, the most sensitive to water deficit (Bergonci et al., 2001; Bergamaschi et al., 2004, 2006, 2007).

The Ky values of the two genotype groups, for the entire growing season, are shown in Figure 1. The slope of the line represents the yield response factor (Ky), as proposed by Doorenbos \& Kassam (1994). For normal resistance genotypes, general Ky was 2.15, whereas for high resistance genotypes it was 1.56 , both higher than the 1.25 value reported by Doorenbos \& Kassam (1994) for the total growing period. These values were also higher than the ones determined by Dagdelen et al. (2006) and Mengu \& Özgürel (2008), in Turkey, which ranged from 0.99 to 1.04. However, values obtained in the present study were close to those observed by Igbadun et al. (2006) in Tanzania (1.90), and by Payero et al. (2008) in Nebraska, USA (from 1.54 to 1.74). According to these authors, even maize being a moderate-resistant crop, it has a very high sensitivity to water stress during flowering period, which is reinforced by the results of our study

Genotypes with higher resistance to water stress, AG 1051, AG 6018, AS 3466 Top, CD 3121, Farroupilha 25, P 3081, P 30F33, and SHS 5050, are those that should be recommended for regions or seasons in which there is a higher risk of water deficit

Table 2. Water deficit sensitivity index (Ky) for the different developmental stages of 26 maize Brazilian genotypes.

\begin{tabular}{|c|c|c|c|c|}
\hline Genotype & $\begin{array}{c}\text { Vegetative } \\
\text { growth }\end{array}$ & Flowering & $\begin{array}{c}\text { Yield } \\
\text { formation }\end{array}$ & Ripening \\
\hline & \multicolumn{4}{|c|}{ Normal resistance } \\
\hline AL Bandeirante & 0.5 & 1.5 & 0.6 & 0.3 \\
\hline AS 1533 & 0.4 & 1.4 & 0.3 & 0.1 \\
\hline BALU 184 & 0.3 & 1.4 & 0.5 & 0.2 \\
\hline BALU 178 & 0.4 & 1.5 & 0.5 & 0.2 \\
\hline BRS 3060 & 0.4 & 1.3 & 0.5 & 0.2 \\
\hline $\mathrm{CO} 32$ & 0.4 & 1.5 & 0.5 & 0.2 \\
\hline DKB 333B & 0.4 & 1.5 & 0.5 & 0.2 \\
\hline DKB 350 & 0.4 & 1.4 & 0.3 & 0.2 \\
\hline DKB 747 & 0.5 & 1.4 & 0.4 & 0.2 \\
\hline P 3041 & 0.4 & 1.5 & 0.5 & 0.2 \\
\hline PL 6880 & 0.4 & 1.5 & 0.3 & 0.2 \\
\hline SHS 4050 & 0.4 & 1.5 & 0.5 & 0.2 \\
\hline SHS 5060 & 0.4 & 1.5 & 0.5 & 0.2 \\
\hline SHS 5070 & 0.4 & 1.5 & 0.5 & 0.2 \\
\hline SHS 4040 & 0.4 & 1.5 & 0.5 & 0.2 \\
\hline XB 7011 & 0.4 & 1.5 & 0.5 & 0.2 \\
\hline XB 7012 & 0.4 & 1.5 & 0.5 & 0.2 \\
\hline \multirow[t]{2}{*}{ XB 8010} & 0.4 & 1.5 & 0.5 & 0.2 \\
\hline & \multicolumn{4}{|c|}{ High resistance } \\
\hline AG 1051 & 0.3 & 1.2 & 0.4 & 0.2 \\
\hline AG 6018 & 0.3 & 1.1 & 0.3 & 0.1 \\
\hline AS 3466 Top & 0.2 & 0.9 & 0.3 & 0.1 \\
\hline CD 3121 & 0.3 & 0.9 & 0.3 & 0.1 \\
\hline Farroupilha 25 & 0.3 & 1.2 & 0.3 & 0.2 \\
\hline P 3081 & 0.2 & 0.7 & 0.2 & 0.1 \\
\hline P $30 F 33$ & 0.4 & 1.0 & 0.2 & 0.1 \\
\hline SHS 5050 & 0.3 & 0.9 & 0.3 & 0.1 \\
\hline
\end{tabular}

during the growing season, like during the fall-winter season ("safrinha") in Southern Brazil. Nevertheless, the genotypes which had normal resistance to water stress, like DKB 333B, should be recommended for regions with lower risk of water deficits, under rainfed conditions, or for drier regions or seasons with irrigation, mainly during the flowering period. Such recommendations are very important for growers and other decision makers, but normally they are not available, since seed companies do not provide Ky values.

The average potential and actual yield estimates, obtained with the calibrated crop yield model for
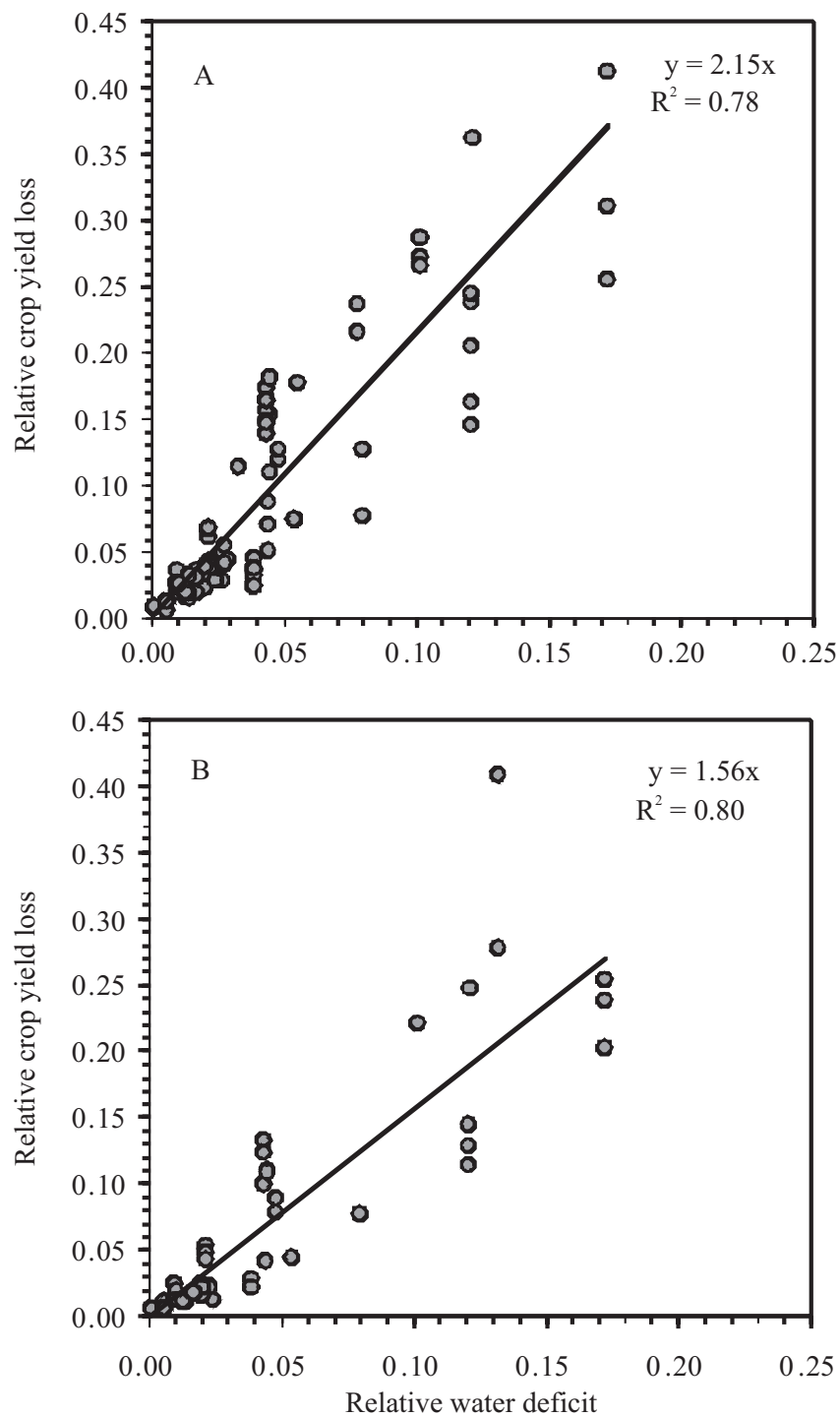

Figure 1. Relationship between relative crop yield loss (1-Ya/Yp) and relative water deficit (1- ETa/ETc), for determining the general Ky value for normal (A) and high (B) resistance to water deficit maize genotypes. 
each one of the 26 genotypes, are shown in Table 3. The potential yields for the assessed locations and periods ranged from $7,951 \mathrm{~kg} \mathrm{ha}^{-1}$ for SHS 4050 to $11,156 \mathrm{~kg} \mathrm{ha}^{-1}$ for AG 1051, but with higher values for individual trials, in which potential yield achieved more than $12,500 \mathrm{~kg} \mathrm{ha}^{-1}$, as observed in Londrina and Senador Canedo for AG 1051 in 2001/2002, and in Cascavel for DKB 747 in 2002/2003. The estimated actual yields were very similar to observed data, with underestimations in 16 , and overestimations in 10 genotypes, with the MBE ranging from -5.7 to $+5.8 \%$. The MAE between observed and estimated Ya ranged from 298 to $1,477 \mathrm{~kg} \mathrm{ha}^{-1}$, which represents, in percentage, errors between 3.9 and $15 \%$, considered acceptable for yield modeling. These errors were similar to those found by Soler et al. (2007), who used the DSSAT CERES-MAIZE model to estimate actual yields of rainfed and irrigated maize genotypes, in the state of São Paulo, Brazil (-10.7 to $11.3 \%)$.

It is important to emphasize that the models used in this study accounted only for the effect of weather variables, like solar radiation, photoperiod, temperature and rainfall. Therefore, other factors as the occurrence of pests, diseases, and nutritional deficiency, in the 244 field trials, were not considered, which could explain part of the errors observed.

The model statistics to estimate Ya for each genotype, in terms of their precision (r), accuracy (d) and performance (c) are shown in Table 3. For some genotypes, like BALU 184, SHS 4040 and P 30F33, the model provided good results, with $\mathrm{c}$ index above 0.7. Nevertheless, for the genotypes BRS 3060, DKB 350, SHS 4050, SHS 5050, SHS 5060, and SHS 5070, the performance of the model was poor, with c index below 0.3 . When all the 244 field trials were considered together to evaluate the performance of the model (Figure $2 \mathrm{~A}$ ), a general $\mathrm{c}$ index of 0.58 was found, which is considered acceptable for modeling purposes (Camargo \& Sentelhas, 1997). For this analysis, the MAE was $960 \mathrm{~kg} \mathrm{ha}^{-1}$.

Figure $2 \mathrm{~B}$ shows the relationship between the observed and the estimated Ya, considering the average Ya for each genotype. Under this approach, the performance of the model was improved, showing that, in general, it has potential to be used as a tool for yield estimation and forecasts. The same conclusion was found by Rolim et al (2001), when comparing the model used in this study with DSSAT model to estimate sunflower actual yield in the states of São Paulo and Paraná.

Table 3. Statistics of the comparison between the observed and the estimated maize yield for the evaluated 26 Brazilian genotypes $^{(1)}$.

\begin{tabular}{|c|c|c|c|c|c|c|c|c|c|}
\hline Genotype & Yp (estimated) & Ya (estimated) & Ya (observed) & MBE $(\%)$ & $\operatorname{MAE}\left(\mathrm{kg} \mathrm{ha}^{-1}\right)$ & $\mathrm{r}$ & $\mathrm{d}$ & $\mathrm{c}$ & $\mathrm{n}$ \\
\hline AG 1051 & 11,156 & 10,701 & 10,694 & 0.1 & 1,235 & 0.76 & 0.84 & 0.63 & 7 \\
\hline AG 6018 & 10,440 & 9,581 & 9,953 & -3.7 & 1,022 & 0.74 & 0.86 & 0.64 & 9 \\
\hline AL Bandeirante & 8,483 & 7,957 & 7,850 & 1.4 & 1,048 & 0.66 & 0.75 & 0.50 & 7 \\
\hline AS 1533 & 9,294 & 8,378 & 8,673 & -3.4 & 931 & 0.65 & 0.77 & 0.50 & 9 \\
\hline AS 3466 Top & 8,717 & 8,003 & 8,204 & -2.4 & 696 & 0.76 & 0.66 & 0.50 & 5 \\
\hline BALU 178 & 8,622 & 7,991 & 7,962 & 0.4 & 921 & 0.63 & 0.77 & 0.49 & 9 \\
\hline BALU 184 & 9,110 & 8,479 & 8,651 & -2.0 & 855 & 0.81 & 0.88 & 0.71 & 10 \\
\hline BRS 3060 & 8,990 & 8,234 & 8,272 & -0.5 & 1,252 & 0.43 & 0.66 & 0.28 & 12 \\
\hline CD 3121 & 9,038 & 8,323 & 8,541 & -2.5 & 922 & 0.64 & 0.78 & 0.50 & 14 \\
\hline $\mathrm{CO} 32$ & 9,465 & 8,729 & 8,573 & 1.8 & 829 & 0.65 & 0.79 & 0.51 & 12 \\
\hline DKB 333B & 9,682 & 9,069 & 9,617 & -5.7 & 1,389 & 0.65 & 0.65 & 0.42 & 5 \\
\hline DKB 350 & 9,898 & 9,483 & 9,693 & -2.2 & 1,447 & 0.47 & 0.60 & 0.28 & 5 \\
\hline DKB 747 & 10,094 & 9,326 & 9,232 & 1.0 & 1,242 & 0.73 & 0.84 & 0.61 & 9 \\
\hline Farroupilha 25 & 9,692 & 9,132 & 9,280 & -1.6 & 1,329 & 0.64 & 0.77 & 0.49 & 8 \\
\hline P 3041 & 10,295 & 9,395 & 9,364 & 0.3 & 523 & 0.70 & 0.84 & 0.59 & 8 \\
\hline P 3081 & 8,797 & 7,815 & 7,969 & -1.9 & 592 & 0.67 & 0.79 & 0.53 & 6 \\
\hline P 30 F33 & 9,396 & 8,731 & 8,904 & -1.9 & 971 & 0.91 & 0.88 & 0.80 & 9 \\
\hline PL 6880 & 8,286 & 7,544 & 7,871 & -4.2 & 944 & 0.58 & 0.61 & 0.35 & 11 \\
\hline SHS 4040 & 8,228 & 7,621 & 7,567 & 0.7 & 298 & 0.83 & 0.89 & 0.74 & 6 \\
\hline SHS 4050 & 7,951 & 7,224 & 7,344 & -1.6 & 679 & 0.37 & 0.60 & 0.22 & 9 \\
\hline SHS 5050 & 8,783 & 8,118 & 8,380 & -3.1 & 689 & 0.27 & 0.55 & 0.15 & 10 \\
\hline SHS 5060 & 9,689 & 8,781 & 8,296 & 5.8 & 1,297 & 0.13 & 0.41 & 0.05 & 10 \\
\hline SHS 5070 & 8,851 & 8,012 & 8,068 & -0.7 & 1,086 & 0.33 & 0.56 & 0.18 & 11 \\
\hline XB 7011 & 9,092 & 8,478 & 8,402 & 0.9 & 1,105 & 0.59 & 0.76 & 0.45 & 12 \\
\hline XB 7012 & 9,180 & 8,577 & 8,743 & -1.9 & 974 & 0.76 & 0.84 & 0.63 & 17 \\
\hline XB 8010 & 8,823 & 8,349 & 8,319 & 0.4 & 720 & 0.70 & 0.83 & 0.59 & 14 \\
\hline
\end{tabular}

${ }^{(1)}$ Yp, potential yield; Ya, actual yield; MBE, mean bias error; MAE, mean absolute error; r, correlation coefficient; d, agreement index; c, performance index; n, number of experiments considered from 1998 to 2006. 

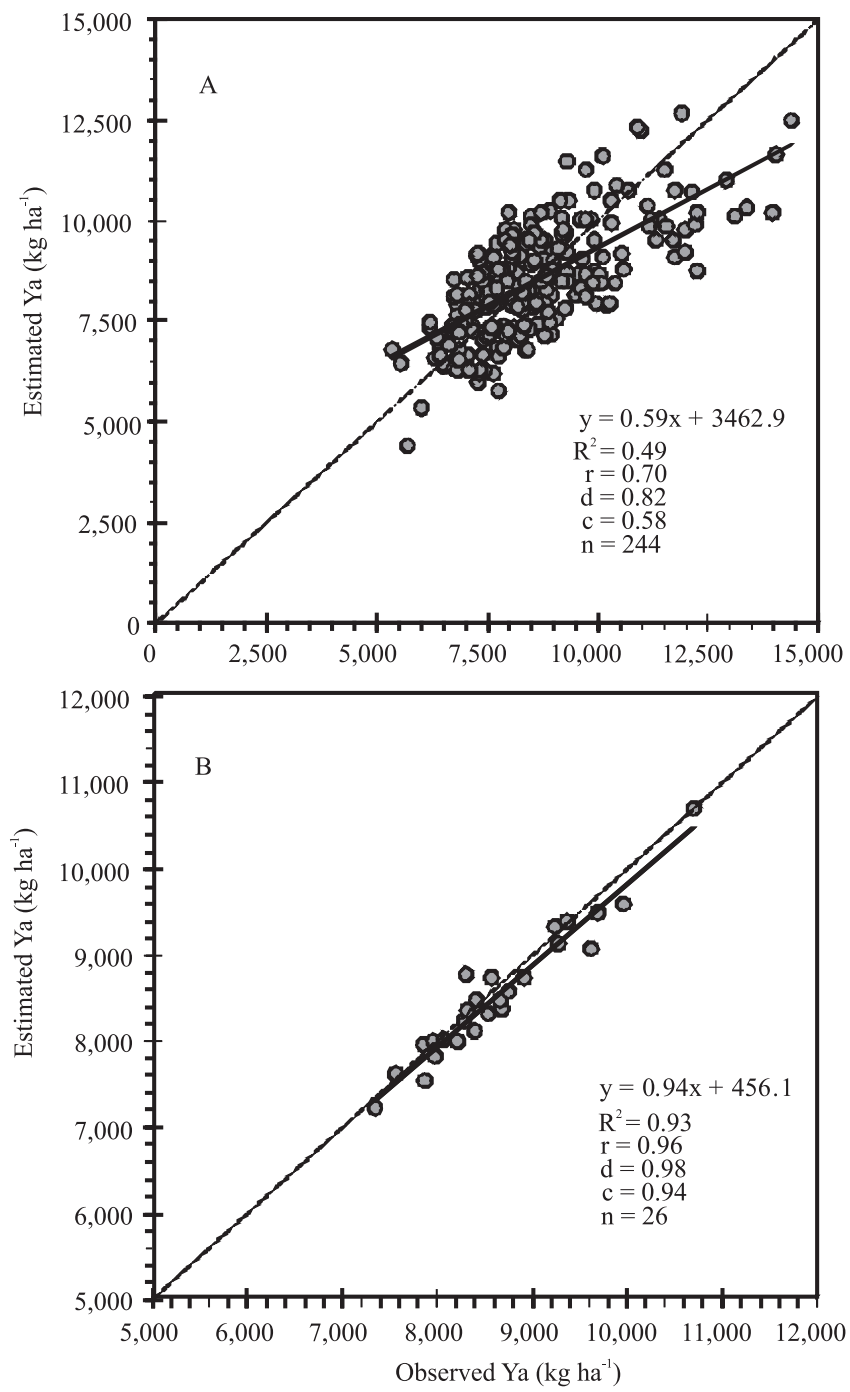

Figure 2. Relationship between the observed and the estimated actual maize yield (Ya) for the 26 Brazilian genotypes, considering the 244 experiments (A) and an average yield by genotypes (B).

\section{Conclusions}

1. The evaluated maize genotypes can be divided into two groups according to their sensitivity to water deficit, one with normal resistance to water stress and another with higher resistance.

2 . The sensitivity of maize genotypes to water deficit is higher during flowering, followed by vegetative growth and yield formation periods. During ripening, genotypes are less sensitive to water stress.

3. The calibrated yield models used result in acceptable estimates of crop actual yield, and have potential to be used as yield forecaster, for crop zoning, and for best sowing dates determination.

\section{Acknowledgements}

To Instituto Tecnológico Simepar, Escola Superior de Agricultura Luiz de Queiroz, Universidade de São Paulo and Sistema Agritempo (Embrapa Informática Agropecuária), for the weather data provided; to Fundação Universidade de Campinas and to Conselho Nacional de Pesquisa e Desenvolvimento for, respectively, scholarship and fellowship granted to authors.

\section{References}

ALlEN, R.G.; PEREIRA, L.S.; RAES, D.; SMITH, M. Crop evapotranspiration: guidelines for computing crop water requirements. Rome: FAO, 1998. 300p. (FAO: Irrigation and Drainage Paper, 56)

BARBIERI, V.; TUON, R.L. Metodologia para estimativa da produção potencial de algumas culturas. Piracicaba: DFM/ Esalq/USP, 1992. 17p.

BERGAMASCHI，H.; DALMAGO，G.A.; BERGONCI，J.I.; BIANCHI, C.A.M.; MÜLLER, A.G.; COMIRAN, F.; HECKLER, B.M.M. Distribuição hídrica no período crítico do milho e produção de grãos. Pesquisa Agropecuária Brasileira, v.39, p.831-839, 2004.

BERGAMASCHI, H.; DALMAGO, G.A.; COMIRAN, F.; BERGONCI, J.I.; MÜLLER, A.G.; FRANÇA, S.; SANTOS, A.O.; RADIN, B.; BIANCHI, C.A.M.; PEREIRA, P.G. Deficit hídrico e produtividade na cultura do milho. Pesquisa Agropecuária Brasileira, v.41, p.243-249, 2006

BERGAMASCHI, H.; WHEELER, T.R.; CHALLINOR, A.J.; COMIRAN, F.; HECKLER, B.M.M. Maize yield and rainfall on different spatial and temporal scales in Southern Brazil. Pesquisa Agropecuária Brasileira, v.42, p.603-613, 2007.

BERGONCI, J.I.; BERGAMASCHI, H.; SANTOS, O.A.; FRANÇA, S.; RADIN, B. Eficiência da irrigação em rendimento de grãos e matéria seca de milho. Pesquisa Agropecuária Brasileira, v.36, p.949-956, 2001.

BERLATO, M.A.; FARENZEIRA, H.; FONTANA, D.C. Associação entre El Niño Oscilação Sul e a produtividade do milho no Estado do Rio Grande do Sul. Pesquisa Agropecuária Brasileira, v.40, p.423-432, 2005.

CAMARGO,A.P. de; SENTELHAS, P.C. Avaliação do desempenho de diferentes métodos de estimativa da evapotranspiração potencial no Estado de São Paulo, Brasil. Revista Brasileira de Agrometeorologia, v.5, p.89-97, 1997.

CAMPOS, A.; COOPER, M.; HABBEN, J.E.; EDMEADES, G.O.; SCHUSSLER, J.R. Improving drought tolerance in maize: a view from industry. Field Crops Research, v.90, p.19-34, 2004.

COELHO, A.M.; CRUZ, J.C.; PEREIRA FILHO, I.A. Rendimento de milho no Brasil: chegamos ao máximo? Piracicaba: Potafos, 2003. 12p. (Informações Agronômicas, 101). 
COMPANHIA NACIONAL DE ABASTECIMENTO. Safras: grãos, safra 2007/08, milho. Disponível em: <http://www.conab. gov.br/conabweb/index.php>. Acesso em: $11 \mathrm{dez} .2008$.

DAGDELEN, N.; YILMAZ, E.; SEZGIN, F.; GÜRBÜZ, T. Water-yield relation and water use efficiency of cotton (Gossypium hirsutum L.) and second crop corn (Zea mays L.) in Western Turkey. Agricultural Water Management, v.82, p.63-85, 2006.

DEMIRBAS, A. Producing and using bioethanol as an automotive fuel. Energy Sources, Part B, v.2, p.391-401, 2007.

DE WIT, C.T. Photosynthesis of leaf canopies. Agricultural Research Report, v.663, p.1-57, 1965.

DOORENBOS, J.; KASSAM, A.H. Efeito da água no rendimento das culturas. Campina Grande: UFPB, 1994. 306p. (FAO. Estudos FAO: Irrigação e Drenagem, 33).

GLOVER, J.; MCCULLOCH, J.S.G. The empirical relation between solar radiation and hours of sunshine. Quarterly Journal of the Royal Meteorological Society, v.84, p.172-175, 1958.

IGBADUN, H.E.; MAHO, H.F.; TARIMO, A.K.P.R.; SALIM, B.A. Crop water productivity of an irrigated maize crop in Mkoji sub-catchment of the Great Ruaha River Basin, Tanzania. Agricultural Water Management, v.85, p.141-150, 2006.

KENNY, G.J.; HARRISON, P.A. Thermal and moisture limits of grain maize in Europe: model testing and sensitivity to climate change. Climate Research, v.2, p.113-129, 1992.

MENGU, G.P.; ÖZGÜREL, M. An evaluation of water yield relations in maize (Zea mays L.) in Turkey. Pakistan Journal of Biological Sciences, v.11, p.517-524, 2008.

MUSIK, J.T.; DUSEK, D.A. Irrigated corn yield response to water. Transactions of the ASAE, v.23, p.92-98, 1980.

OUDA, S.A.E.F.; MOHAMED, S.G.; KHALIL, F.A. Modeling the effect of different stress conditions in maize productivity using yield-stress model. International Journal of Natural and Engineering Sciences, v.2, p.57-62, 2008.
PAYERO, J.O.; TARKALSON, D.D.; IRMAK, S.; DAVISON, D.; PETERSEN, J.L. Effect of irrigation amounts applied with subsurface drip irrigation on corn evapotranspiration, yield, water use efficiency and dry matter production in a semiarid climate. Agricultural Water Management, v.95, p.895-908, 2008.

PEREIRA, A.R.; ANGELOCCI, L.R.; SENTELHAS, P.C. Agrometeorologia: fundamentos e aplicações práticas. Guaíba: Agropecuária, 2002. 478p.

PIMENTEL, D.; PATZEK, T.W. Ethanol production using corn, switchgrass, and wood; biodiesel production using soybean and sunflower. Natural Resource Research, v.14, p.65-76, 2005.

ROLIM, G. de S.; SENTELHAS, P.C.; BARBIERI, V. Planilha no ambiente Excel ${ }^{\mathrm{TM}}$ para os cálculos de balanços hídricos: normal, sequencial, de cultura e de produtividade real e potencial. Revista Brasileira de Agrometeorologia, v.6, p.133-137, 1998.

ROLIM, G. de S.; SENTELHAS, P.C.; UNGARO, M.R.G. Análise de risco climático para a cultura de girassol, em algumas localidades de São Paulo e do Paraná, usando os modelos DSSAT/ OILCROP-SUN e FAO. Revista Brasileira de Agrometeorologia, v.9, p.91-102, 2001.

SOLER, C.M.T.; SENTELHAS, P.C.; HOOGENBOOM, G. Application of the CSM-CERES-Maize model for planting date evaluation and yield forecasting for maize grown off-season in a subtropical environment. European Journal of Agronomy, v.27, p. 165-177, 2007.

THORNTHWAITE, C.W. An approach toward a rational classification of climate. Geographical Review, v.38, p.55-94, 1948.

THORNTHWAITE, C.W.; MATHER, J.R. The water balance. New Jersey: Drexel Institute of Technology, 1955. 104p. (Publications in Climatology).

WILLMOTT, C.J.; ACKLESON, S.G.; DAVIS, R.E.; FEDDEMA, J.J.; KLINK, K.M.; LEGATES, D.R.; O'DONNELL, J.; ROWE, C.M. Statistics for the evaluation and comparison of models. Journal of Geophysical Research, v.90, p.8995-9005, 1985.

Received on March 2, 2009 and accepted on June 23, 2009

Pesq. agropec. bras., Brasília, v.44, n.7, p.653-660, jul. 2009 